ks. Stanisław Wronka

\title{
Chrystus najpełniejszym obrazem Boga
}

Pośród różnych określeń używanych przez autorów Nowego Testamentu

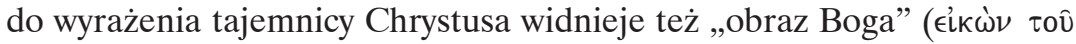
$\theta \in 0 \hat{)}$. Chrystus jest tak nazwany dwukrotnie w listach św. Pawła: 2 Kor 4, 4, i Kol 1, 15 . Treściowe paralele, jednak bez samego terminu „obraz”, można nadto znaleźć w Ewangelii Janowej (1, 3; 5, 17-19; 10, 30; 12, 45; 14, 9; 17, 5. 21-22. 24) oraz w Liście do Hebrajczyków $(1,3)$.

Określenie „obraz Boga” występuje w pismach Platona (por. Timajos, 92c) i było znane w świecie hellenistycznym (np. Ptolemeusza Epifanesa nazywano „żywym obrazem Zeusa”). Ale wpływ koncepcji platońskich i hellenistycznych form dworskich gloryfikujących władców na Pawła jest tu raczej wątpliwy. Wystarczy w tym względzie odwołać się do biblijnego terminu „obraz” użytego w sensie przenośnym w Księdze Rodzaju (1, 26-27; 5, 1; 9, 6) i w księgach mądrościowych (Mdr 2, 23; 7, 26; Syr 17, 3), po który sięgała również literatura judaizmu hellenistycznego ${ }^{2}$. Paweł bowiem, dawny rabin, korzysta przede wszystkim z dziedzictwa Starego Testamentu. Aby więc w pełni zrozumieć treść, jaką zawarł w określeniu „obraz Boga” odniesionym do Chrystusa, trzeba prześledzić znaczenie tego określenia w odniesieniu do człowieka i Mądrości. Paweł odwołuje się do nich w sposób mniej lub bardziej wyraźny, kiedy mówi o Chrystusie jako „obrazie Boga”.

\section{Człowiek stworzony „na obraz Boży” (Rdz 1, 27)}

W pierwszym opisie stworzenia czytamy: „A wreszcie rzekł Bóg: 'Uczyńmy człowieka na Nasz obraz, podobnego Nam’ [...]. Stworzył więc Bóg człowieka na swój obraz, na obraz Boży go stworzył: stworzył mężczyznę i niewiastę" ( $\mathrm{Rdz} 1,26-27)^{3}$.

${ }^{1}$ Wielu egzegetów neguje dziś Pawłowe autorstwo Listu do Kolosan, jednak ich argumenty nie przesądzają definitywnie tej kwestii; por. J.-N. AlETti, Lettera ai Colossesi. Introduzione, versione, commento, Bologna 1994, s. 28-31, 232-234.

${ }^{2}$ Por. A. Jankowski, Listy więzienne św. Pawła. Wstęp - przekład z oryginatu - komentarz, Poznań 1962, s. 226; A. Vanhoye, Situation du Christ. Hébreux 1-2, Paris 1969, s. 71-75; 
„Obraz” jest tutaj thumaczeniem hebrajskiego wyrazu șélem ${ }^{4}$ (w LXX

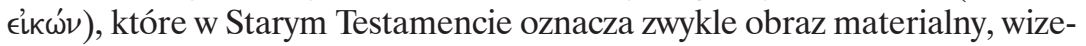
runek zewnętrzny bez uwzględniania strony moralnej i duchowej (por. Am 5, 26; $1 \mathrm{Sm}$ 6, 5. 11; $2 \mathrm{Krl}$ 11, 18; Ez 7, 20; 16, 17; 23, 14). W naszym tekście stosunek obrazu do przedstawionej na nim osoby nie jest tylko zewnętrzny i przypadłościowy. Wskazuje na to przyimek $b^{e}$ stojący przed sélem ( $b^{e} s a l$ ménn̂̂) $)^{5}$, a także pojęcie „tchnienia” użyte w drugim opisie stworzenia (Rdz $2,7)$. Oddaje ono dobrze ścisły związek zachodzący między Bogiem a człowiekiem, który „,nie może istnieć niezależnie od tego, którego jest obrazem”.

Drugie wyrażenie hebrajskie demût (w LXX ó $\mu$ ó $\omega \mu \alpha)$, oznaczające w Starym Testamencie podobieństwo konkretne (por. $2 \mathrm{Krl}$ 6, 10; Ez 1, 5. 22. $26.28 ; 8,2 ; 10,1.21-22$ ) lub abstrakcyjne (por. Ez 1, 10. 16; 10, 10), stanowi glosę wyjaśniająca, jak na to wskazuje partykuła wiążąca $k^{e}$ (jako) stojąca przed nim (kidmûtén̂û). Osłabia ono znaczenie „obrazu”, wyklucza w nim równość. Oba wyrażenia są tutaj synonimami. Autor używa ich w sensie przenośnym, chcąc powiedzieć, że Bóg uczynił człowieka podobnym do siebie $^{7}$, „niewiele mniejszym od istot niebieskich” (Ps 8, 6) . $^{8}$

Stworzenie człowieka „na obraz Boży” oznacza więc, że człowiek wskazuje na Stwórcę jako swój prawzór, od którego zależy, że wykazuje pewne podobieństwo z Nim i uczestniczy w pewnym stopniu w Jego rzeczywistości, ale bez całkowitego upodobnienia, a tym bardziej bez zrównania.

To podobieństwo wyraża się najpierw w tym, że człowiek jest bytem osobowym ${ }^{9}$. Obdarzony rozumem i wolą (por. Syr 15, 14-17; 17, 6-8), zdolny jest

J.-N. Aletti, Lettera ai Colossesi, dz. cyt., s. 90-93, 104-106. Ten ostatni odrzuca jednak wpływ Rdz 1, 26-27 w 2 Kor 4, 4 i Kol 1, 15, ponieważ jego zdaniem „bycie obrazem Boga” znaczy co innego w wypadku człowieka, a co innego w wypadku Chrystusa. Opinia ta wydaje się zbyt radykalna, bo trudno przecież zaprzeczyć, że podstawowa idea jest w tych tekstach wspólna.

${ }^{3}$ Wszystkie cytaty biblijne w języku polskim za: Biblia Tysiąclecia, Poznań ${ }^{5} 2002$.

${ }^{4}$ Transliteracja wyrazów hebrajskich za: S. WRONKA, Transliteracja i transkrypcja alfabetu hebrajskiego, „Ruch Biblijny i Liturgiczny” 1 (2004), s. 45-58.

${ }^{5}$ Por. S. ŁACH, Księga Rodzaju. Wstęp - przekład z oryginatu - komentarz, Poznań 1962, s. 193.

${ }^{6}$ X. LÉOn-Dufour, Człowiek, [w:] Słownik teologii biblijnej, red. nacz. X. Leon-Dufour, tł. i oprac. K. Romaniuk, Poznań-Warszawa ${ }^{21982, ~ s . ~} 184$.

${ }^{7}$ Por. S. Łach, Księga Rodzaju, dz. cyt., s. 193.

${ }^{8}$ Możliwe jest także tłumaczenie: „niewiele mniejszym od Boga” lub „aniołów”, jak ma

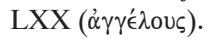

${ }^{9}$ Por. S. LACH, Księga Rodzaju, dz. cyt., s. 193-194; M. Peter, Wykład Pisma Świętego Starego Testamentu, Poznań 1959, s. 37; K. Romaniuk, Stworzenie człowieka jako przejaw odwiecznej dobroci Boga, [w:] Drogi zbawienia. Od Biblii do Soboru, praca zbiorowa pod red. B. Przybylskiego, Poznań-Warszawa-Lublin 1970, s. 29. Pomijamy tu społeczny wymiar człowieka, który także stanowi o jego podobieństwie do Stwórcy. Bóg stworzył człowieka jako mężczyznę i niewiastę, a więc jako wspólnotę osób (por. Rdz 1, 27; 2, 23-24), gdyż sam jest wspólnotą osób w tajemnicy Trójcy Świętej. Znamienne jest użycie w 1, 26 liczby mnogiej w odniesieniu 
do myślenia, mówienia, działania i osądzania swych dzieł. Może Boga poznać (por. Mdr 13, 1-6; Rz 1, 19-20) i nawiązać z Nim dialog. „Obraz Boży” w człowieku wydaje się być dalej identyczny ze stanem „chwały i blasku” (kābôố

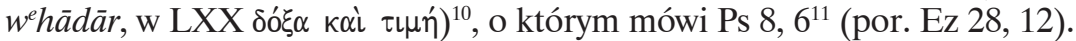
Człowiek uczestniczy w pięknie i harmonii Boga. Przejawia się to nie tylko w duchowej, ale i w fizycznej stronie człowieka, skoro Adam może przekazać otrzymany „obraz” potomkom (por. Rdz 5, 3), a zabójstwo człowieka unicestwia „obraz Boży” w nim (por. 9, 6) ${ }^{12}$. Księga Mądrości pogłębia i uduchawia naukę o „obrazie Bożym” w człowieku poprzez dorzucenie jeszcze jednego elementu: „Bo do nieśmiertelności ('€片’ $\left.\alpha \phi \theta \alpha \rho \sigma^{\prime} \alpha\right)$ Bóg stworzył człowieka -

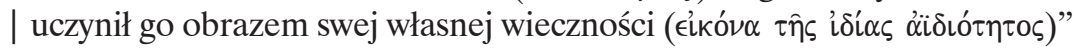
$(2,23)^{13}$. Pierwsi rodzice otrzymali przywilej nieśmiertelności fizycznej, ale go utracili przez swój grzech. Stąd zaczęli podlegać śmierci, a ich potomkowie żyli coraz krócej (por. Rdz 5). Autor Mdr stwierdza w polemice z bezbożnymi, którzy nie wierzyli w żadną odpłatę po śmierci, że w nagrodę za dobre życie sprawiedliwi będą się cieszyć wyjątkowym istnieniem po śmierci, a nie tylko - jak wszyscy inni - nieśmiertelnością samej duszy ${ }^{14}$.

Swą funkcję obrazu spełnia człowiek głównie w dwóch rodzajach działania: naśladując Boga w Jego panowaniu ma poddawać całą ziemię pod swą władzę (por. Rdz 1, 26. 28; Ps 8, 7-9; Syr 17, 2-4), odtwarzając zaś

zarówno do Boga, jak i do człowieka, którą konsekwentnie oddała Biblia Poznańska, t. 1,

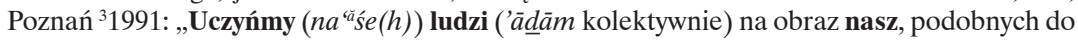
nas, a niech władają ( $\left.w^{e} j i r d \hat{u}\right)$ ". Ta ludzka wspólnota została przez grzech zachwiana; człowiek oddalił się od człowieka (por. 3, 12-13. 16; 4, 8-9). Będzie ona przywrócona w Chrystusie, który jest „Głową Ciała - Kościoła” (Kol 1, 18; por. Ef 1, 10; 5, 23. 29-32; Dz 2, 42. 44; 4, 32).

${ }^{10}$ Pojęcie „obrazu” i „chwały” mają w Piśmie Świętym często znaczenie synonimiczne; por. K. Romaniuk, Stworzenie człowieka jako przejaw odwiecznej dobroci Boga, art. cyt., s. 28; P. LAMARChe, Obraz, [w:] Stownik teologii biblijnej, dz. cyt., s. 594.

${ }^{11}$ Pozostaje on w ścisłym związku z Rdz 1, jest jakby komentarzem do opisu stworzenia. W wypadku autorstwa Dawidowego natomiast Ps 8 stanowił materiał do rozważań dla redaktora-kapłana z VI w. przed Chr.; por. J. RosŁon, Soteriologiczny sens obrazu Bożego w człowieku, „Collectanea Theologica” 3 (1971), s. 10.

${ }^{12}$ Por. K. Romaniuk, Stworzenie człowieka jako przejaw odwiecznej dobroci Boga, art. cyt., s. 29. Myśl hebrajska nie oddzielała zresztą ostro pierwiastka duchowego od materialnego w człowieku, ale traktowała go jako złożoną jedność, w której ciało objawia duszę; por. A. GELIN, Pismo Święte o człowieku, Paris 1971, s. 13, 16, 18, 26-27. S. ŁACH, Księga Rodzaju, dz. cyt., s. 193, oraz M. Peter, Wykład Pisma Świętego Starego Testamentu, dz. cyt., s. 37, akcentując niematerialność Boga, wykluczają fizyczne podobieństwo między Nim a człowiekiem.

${ }_{13}$ 'A $\phi \propto \alpha \rho \sigma^{\prime} \alpha$ znaczy dokładnie „niezniszczalność”. Orygenes, Lucjan oraz kodeksy ma-

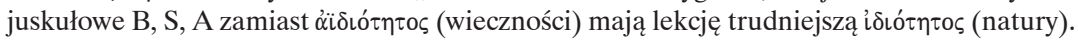
Biorąc jednak pod uwagę paralelizm stychów, trzeba w „naturze” Bożej widzieć tu przede wszystkim wieczność.

${ }^{14}$ Por. M. Gilbert, Mądrość Salomona, t. 2, Kraków 2002, s. 92-94; K. Romaniuk, Księga Mądrości. Wstęp - przekład z oryginału - komentarz, Poznań 1969, s. 112. 
w sobie obraz ojcostwa Bożego ma się rozmnażać, aby napełnić ziemię (por. $\mathrm{Rdz} 1,28)$. Ma to robić kierując się zawsze sprawiedliwością, świętością i prawością serca na podobieństwo swego Stwórcy (por. Mdr 9, 1-3) i w ten sposób objawiać Jego mądrość i miłość.

Człowiek stworzony „na obraz Boży” jest panem ziemi, reprezentantem Boga i uosobieniem Jego obecności, a nawet więcej - jest jakby synem Boga (por. Łk 3, 38), bo otrzymał udział w nieśmiertelnym życiu, takim jakie jest właściwe Bogu. Tylko on może pretendować do tego, by być obrazem Boga transcendentnego, przewyższającego wszystko. Dlatego nie wolno sobie sporządzać żadnych innych obrazów Boga (por. Wj 20,4). To stanowi o najwyższej wśród ziemskich stworzeń godności człowieka ${ }^{15}$.

\section{Mądrość „obrazem dobroci Boga” (Mdr 7, 26)}

Mimo że człowiek w momencie stworzenia był „wiernym obrazem Stwórcy w stopniu przez Niego zamierzonym" ${ }^{16}$, to przecież nie był doskonałym obrazem. Przewyższa go pod tym względem Mądrość, do której także odniesiony jest termin „obraz”.

Istnieje ona od wieków, od początku, nim ziemia powstała, Jahwe stworzył ją, swe arcydzieło przed swymi czynami, od dawna (por. Prz 8, 22-23) ${ }^{17}$. Pochodzi wprost od samego Boga, bo wyszła z ust Najwyższego (por. Syr 24, 3), jest „tchnieniem mocy Bożej | i przeczystym wypływem chwały Wszechmocnego" (Mdr 7, 25). Autor Księgi Przysłów nie zawaha się nawet powiedzieć, że Mądrość jest „poczęta” $(8,25)$ i „zrodzona” $(8,24)$ przez Boga. W Mdr 7, 26 znajdujemy określenie istoty Mądrości, jest ona

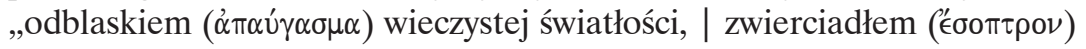

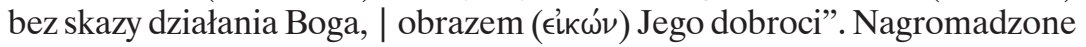
tu terminy tworzą szereg rosnący: odblask, zwierciadło, obraz. Nietrudno dostrzec, że autor zmierza do utożsamienia Mądrości z samym Bogiem ${ }^{18}$. Potwierdzają to wyraźnie przymioty przypisane jej w Mdr 7, 22-23. Sama

${ }^{15}$ Por. C. Jakubiec, Pradzieje biblijne. Teologia Genesis 1-11, Poznań-Warszawa-Lublin 1968, s. 24, 26; P. LAMARChe, Obraz, art. cyt., s. 594.

${ }^{16}$ K. Romaniuk, Stworzenie człowieka jako przejaw odwiecznej dobroci Boga, art. cyt., s. 30. Wskazują na to słowa Rdz 1,31: „A Bóg widział, że wszystko, co uczynił, było bardzo dobre”, które w pierwszym rzędzie odnoszą się do człowieka.

${ }^{17}$ W. 22 jest wieloznaczny. Sam czasownik hebrajski qnh, oddany w LXX przez „stworzył”

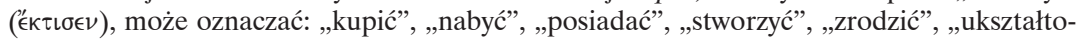
wać”; por. T. M. McCreesh, Księga Przysłów, [w:] Katolicki komentarz biblijny, red. nauk. wyd. oryg. R. E. Brown, J. A. Fitzmyer, R. E. Murphy, red. nauk. wyd. pol. W. Chrostowski, Warszawa 2001, s. 531 (Prymasowska Seria Biblijna, 17); L. Alonso-SchöKel, Sapienciales I. Proverbios, Madrid 1984, s. 239-240.

${ }^{18}$ Por. K. Romaniuk, Księga Mądrości, dz. cyt., s. 158. 
ich liczba (21, czyli 3×7) jest symboliczna i oznacza najwyższą doskonałość. Niektóre z nich - świętość, jedyność, wszechmoc, wszechwiedza, przenikanie wszelkich duchów - są wprost przymiotami Boga. Przypisanie ich Mądrości uwydatnia jej charakter osobowy i wynosi ją niemal do godności Osoby Boskiej. Jako „zwierciadło bez skazy działania Boga” była Mądrość ze Stwórcą przy stwarzaniu świata (por. Prz 8, 27-30), a później kierowała dziejami ludzkości, zwłaszcza historią Izraela, wybawiając sprawiedliwych z różnych opresji (por. Mdr 10-19). Dla ludzi jest niedostępna (por. Koh 7, 23).

W pojęciu „obraz” odniesionym do Mądrości zawiera się więc jej Boskie pochodzenie, niemal równość z Bogiem i godność Osoby Boskiej oraz współdziałanie z Nim. Wprawdzie Stary Testament nie mówi tego wyraźnie ze względu na ścisły monoteizm, który zdawał się wykluczać istnienie osób w Bogu, niemniej nietrudno dostrzec, że autorzy Starego Testamentu widzą w Mądrości istotę Bożą, transcendentną. Pojęcie „obrazu” nasycone bogatą treścią służy im właśnie do tego, aby ukazać tożsamość Mądrości z Bogiem bez narażania monoteizmu na uszczerbek.

\section{Chrystus obrazem Boga}

Odnosząc termin „obraz” do Chrystusa (2 Kor 4, 4; Kol 1, 15), nawiązuje św. Paweł pośrednio do Rdz 1, 26-27. Adam bowiem jest dla niego „pierwszym człowiekiem” (1 Kor 15, 47) i „typem Tego, który miał przyjść” (Rz 5, 14), a Chrystusa z kolei nazywa „drugim Człowiekiem” i „ostatnim Adamem" (1 Kor 15, 47. 45). Posługuje się tu Paweł interpretacjami rabinów, którzy już uważali Ps 8 za mesjański ${ }^{19}$, oraz teorią Filona o dwóch Adamach zaczerpniętą z judaizmu aleksandryjskiego ${ }^{20}$.

Drugim, ważniejszym źródłem inspiracji dla Pawła jest Mądrość. W jej świetle dostrzega on w Chrystusie prawdziwy i jedyny obraz Boga. Wszystkie rysy Mądrości - Boskie pochodzenie, niemal tożsamość z Bogiem i godność Osoby Boskiej oraz obecność przy stwarzaniu świata i kierowanie jego dziejami - przenosi Apostoł w Kol 1, 15-20 na Chrystusa, w którym zajaśnieją one pełnym blaskiem. W 1 Kor 1, 24. 30; 2, 7 nazwie Go wprost „mądrością Bożą”. Również autor Listu do Hebrajczyków $(1,3)$ wyraźnie nawiąże do $\operatorname{Mdr} 7,26^{21}$.

\footnotetext{
${ }^{19}$ Por. J. Jeremias, 'A $\delta \alpha \dot{\mu} \mu$, [w:] Theologisches Wörterbuch zum Neuen Testament, hrsg. von G. Kittel, t. 1, Stuttgart 1957, s. 142-143. Wyraźnie Ps 8 odniesiony jest do Chrystusa w 1 Kor 15, 27 oraz w Hbr 2, 5-10.

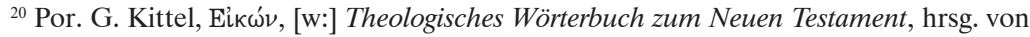
G. Kittel, t. 2, Stuttgart 1960, s. 395.

${ }^{21}$ Por. P. Lamarche, Obraz, art. cyt., s. 595; J.-N. Aletti, Lettera ai Colossesi, dz. cyt., s. 90-93, 104-106; A. VANHOYe, Situation du Christ, dz. cyt., s. 71-75.
} 


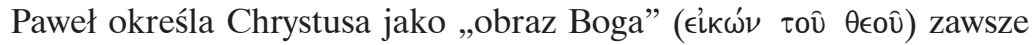
w podniosłym kontekście. W 2 Kor 4, 1-6 mówi o posłudze słowa, której przedmiotem jest „Chrystus Jezus jako Pan” (4, 5), natomiast Kol 1, 15-20 stanowi hymn chrystologiczny o bezwzględnym prymacie Chrystusa. „Obraz” użyty w takim kontekście musi ujawniać istotę Chrystusa, wyrażać najgłębszą prawdę o Nim, jaką Paweł ma do przekazania ${ }^{22}$. Spróbujemy wydobyć tę prawdę poprzez analizę wskazanych tekstów w kolejności chronologicznej: rozpoczniemy od 2 Kor, potem przejdziemy do Kol, a na końcu zajmiemy się prologiem Listu do Hebrajczyków, który stanowi pewną syntezę.

2 Kor 4, 4

W 2 Kor św. Paweł pisze: „A jeśli nawet Ewangelia nasza jest ukryta, to tylko dla [...] niewiernych, których umysły zaślepił bóg tego świata, aby nie olśnił ich blask Ewangelii chwały Chrystusa, który jest obrazem Boga. Nie głosimy bowiem siebie samych, lecz Chrystusa Jezusa jako Pana, a nas - jako sługi wasze przez Jezusa. Albowiem Bóg, Ten, który rozkazał ciemnościom, by zajaśniały światłem, zabłysnął w naszych sercach, by olśnić nas jasnością poznania chwały Bożej na obliczu Chrystusa” (4, 3-6).

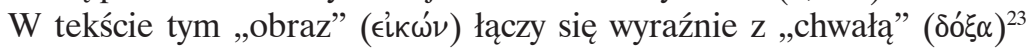

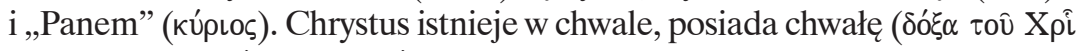

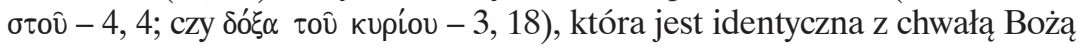

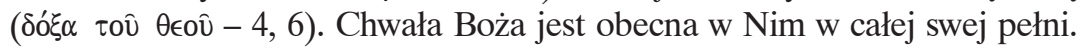
Jej współposiadanie przypisane jest, podobnie jak i godność „bycia obrazem Boga”, Osobie Chrystusa, a więc i Jego człowieczeństwu, które w 2 Kor 4, 6

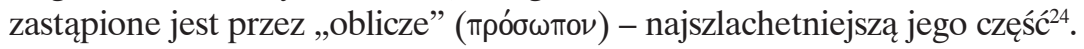
Nie tylko Jednorodzony Syn, „który jest w łonie Ojca” (J 1, 18), miał tę chwałę „wpierw, zanim świat powstał” $(17,5)$, kiedy istniał „w postaci Bożej” ( $€ \nu$ $\mu о \rho \phi \hat{~} \theta \epsilon o \hat{}$; Flp 2, 6). Miał ją także Chrystus, który przez zmartwychwstanie i wniebowstąpienie „wszedł” (Łk 24, 26) do chwały Bożej (por. 1 P 1, 21; $1 \mathrm{Tm} 3,16$; Dz 7, 55; 22, 11), został wywyższony ponad wszystko (por. Flp 2,9) i który w czasie paruzji ukaże się w swoim uwielbionym ciele (por. 3, 21), a więc w pełni chwały (por. Mt 16, 27; 24, 30; 25, 31; Kol 3, 4). Jezus posiadał tę chwałę już w czasie ziemskiego życia, wtedy jednak była ona ukryta i nie rozbłysła pełnym blaskiem na Jego obliczu poza momentem przemienienia

${ }^{22}$ Por. K. Prümm, Diakonia Pneumatos. Der zweite Korintherbrief als Zugang zur apostolischen Botschaft. Auslegung und Theologie, t. 1, Rom-Freiburg-Wien 1967, s. 224.

${ }^{23}$ Podobnie w 1 Kor 11, 7: „Mężczyzna [...] jest obrazem i chwałą Boga”.

${ }^{24}$ Por. K. Prümm, Diakonia Pneumatos, dz. cyt., t. 1, s. 216, 221.

${ }^{25}$ W opisie Mateuszowym „chwała” wyrażona jest pojęciem ,światła” ( $\left.\phi \hat{\omega} \varsigma\right)$, które jest jakby odbiciem chwały. Pismo Święte odnosi „światło” zarówno do Boga (por. Wj 24, 17; Ps 104 [103], 2; Ez 1, 27-28; Ha 3, 4; 1 Tm 6, 16; Jk 1, 17; 1 J 1, 5), jak i do Chrystusa (por. 
(por. Łk 9, 32)25. Przychodząc bowiem na świat Jezus przyjął „postać sługi”

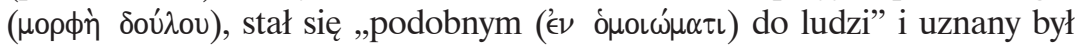

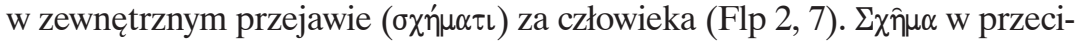
wieństwie do $\mu$ офф́n nie odzwierciedla najgłębszej istoty (por. 1 Kor 7,31), ale oznacza całokształt tego, co ukazuje się zmysłom. Również ó $u$ oí $\omega \mu \alpha$ prawie zawsze oznacza u Pawła jedynie rzeczywistą analogię (por. Rz 5, 14; 6, 5; $8,3)^{26}$. A więc Chrystus, będąc w pełni człowiekiem, na co wskazuje $\mu$ opфì

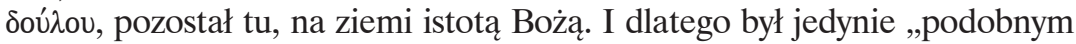
do ludzi” w zewnętrznym przejawie (Flp 2, 7; por. Rz 8, 3$)^{27}$. Jako Bóg miał udział w chwale Bożej i tę chwałę objawiał ludziom. Dzięki Niemu stała się ona dostępna dla nas, możemy ją poznać i osiągnąć (por. 2 Kor 4, 6; J 1, 14; 2, 11).

Chrystus jest zatem obrazem Boga przez to, że ma istnienie pełne chwa-

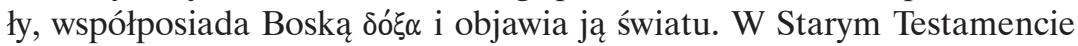
„wyrażenie 'chwała Jahwe' [ $\left.k^{e} \underline{b} \hat{o} \underline{d} J H W H\right]$ oznacza Boga samego, gdy ukazuje się w swym majestacie, w blasku swej świętości, w całej mocy swojego bytu"28. Jej ukazywanie się ,jest oślepiającym wprost promieniowaniem Bożej istoty"29 (por. Wj 24, 10. 15-17; 33, 18-22; Kpł 9, 23; Pwt 5, 22-24). W Nowym Testamencie „chwała” również oznacza najczęściej naturę Bożą, o ile objawia się ona w blasku chwały i światła (por. J 1, 14; 2, 11) . $^{30}$.

Bardzo bliska pojęciu „chwały” jest $\mu$ opфฑ́. „Postać” jest także tym, co ujawnia się na zewnątrz, ale nie w przeciwieństwie do istoty. Pojęcie to wyraża istotę i staje się wprost jej określeniem ${ }^{31}$. Oznacza sposób bytowania uzależniony od istoty, zewnętrzny przejaw ukazujący istotę bytu. „Istnieć w postaci Bożej” znaczy być spowitym w chwałę należną tylko Bogu, a więc być Bogiem ${ }^{32}$. Chrystus ostatecznie jest obrazem Boga przez to, że dzieli z Bogiem tę samą naturę i objawia ją w pełni światu (por. Kol 2, 9).

Współistotność Chrystusa z Bogiem wyraża jeszcze mocniej tytuł „Pana” (кúpıьৎ), który w naszym tekście łączy się z „obrazem”. Przypisując go Chrystusowi Paweł wprost zrównuje Go z Bogiem, skoro w 2 Kor 3,

J 1, 4. 9; 8, 12; 9, 5); por. K. Prümm, Diakonia Pneumatos, dz. cyt., t. 1, s. 223; A. Feuillet, P. Grelot, Światto i ciemności, [w:] Słownik teologii biblijnej, dz. cyt., s. 959, 961-962.

${ }^{26}$ Por. A. Jankowski, Listy więzienne św. Pawta, dz. cyt., s. 116.

${ }^{27}$ Por. W. BAUER, Griechisch-deutsches Wörterbuch zu den Schriften des Neuen Testaments und übrigen urchristlichen Liteartur, Berlin ${ }^{5} 1958$, s. 1122.

${ }^{28}$ D. Mollat, Chwała, [w:] Stownik teologii biblijnej, dz. cyt., s. 135.

${ }^{29}$ Tamże, s. 136.

${ }^{30}$ Por. S. ŁACH, List do Hebrajczyków. Wstęp-przekład z oryginału-komentarz-ekskursy, Poznań 1959, s. 127.

${ }^{31}$ Stary Testament i Paweł nie posiadają precyzyjnego terminu na określenie istoty; por. R. Bultmann, Der zweite Brief an die Korinther, Göttingen 1976, s. 97.

${ }^{32}$ Por. A. Jankowski, Listy więzienne św. Pawła, dz. cyt., s. 113, 529. J. Gnilka, Der Philipperbrief, Freiburg-Basel-Wien 1968, s. 114, oddaje $\mu$ орфи́ przez „Daseinsweise”. 
16 cytuje Wj 34, 34, gdzie кúpıos jest tłumaczeniem najświętszego imienia Boga JHWH. Nadto w 3, 17 przypisuje Chrystusowi Ducha ( Rodzajnik tó wskazuje, że chodzi tu raczej o Trzecią Osobę Boską niż o moc Boga czy strefę działania Ducha Świętego w człowieku.

Mówiąc o Panu, Paweł ma na myśli nie tylko Chrystusa wywyższonego, ale także Jezusa Mesjasza, którego głosi ,jako Pana” (2 Kor 4, 5) i nazywa „ukrzyżowanym Panem chwały” (1 Kor 2, 8). W tym ostatnim wyrażeniu

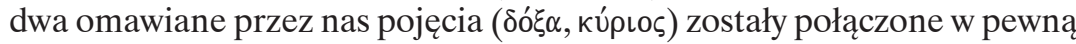
syntezę: Chrystus posiada Boską chwałę jako Pan. To, że Boski kúpıos jest równocześnie człowiekiem, nie ogranicza wcale кupıó ๆฺs, podobnie jak

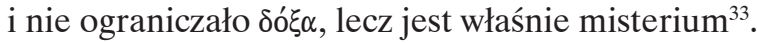

Kol 1,15

Idea równości Chrystusa z Bogiem zakładana jest także w Kol 1, 15,

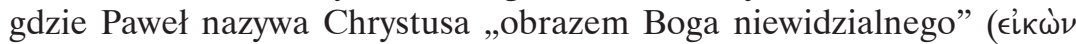

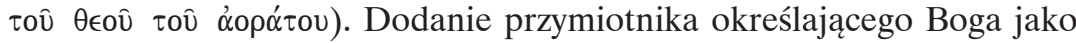

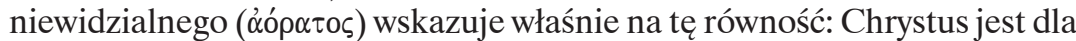
świata tak nieuchwytny, daleki i niewidzialny, jak sam Bóg ${ }^{34}$. Przymiotnik ten wyraża zarazem i inną prawdę, że Chrystus jest pełnym objawieniem $(\epsilon \pi \iota \phi \alpha ́ v \epsilon L \alpha)$ Boga. Tylko przez Niego możemy poznać zasadniczo niepoznawalnego, bo niewidzialnego Boga (por. Mt 11, 27; Łk 10, 22; J 1, 18; 6, $46 ; 8,19 ; 12,45 ; 14,7.9 ; 17,26)^{35}$.

Chrystus jest obrazem działania Boga (por. J 5, 17) ${ }^{36}$. „Albowiem to samo, co On [Ojciec] czyni, podobnie i Syn czyni” $(5,19)$. Bóg jest przede wszystkim Stwórcą. On „stworzył świat i wszystko, co w nim istnieje” (Dz 17, 24), w Nim „żyjemy, poruszamy się i jesteśmy” (17, 28). Chrystus ma w tym dziele swój udział: „w Nim zostało wszystko stworzone [...] przez Niego i dla Niego" (Kol 1, 16; por. J 1, 3). Trzy przyimki użyte tu przez

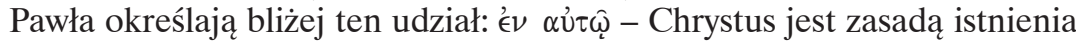
wszechrzeczy ( $\tau \dot{\alpha} \pi \alpha \dot{\alpha} \nu \tau)$, punktem przecięcia się wszystkich linii tworzących we wszechświecie, ostatecznym ośrodkiem, który nadaje wszystkiemu jed-

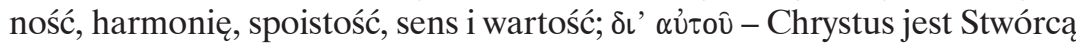
jako przyczyna sprawcza, narzędziowa, Bóg przez Niego wszystko stworzył;

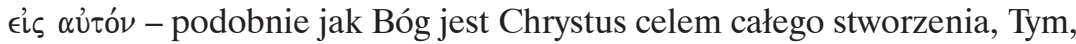

\footnotetext{
${ }^{33}$ Por. K. Prümm, Diakonia Pneumatos, dz. cyt., t. 1, s. 219-220.

${ }^{34}$ Por. H. Langkammer, Hymny chrystologiczne Nowego Testamentu. Najstarszy obraz Chrystusa, Katowice 1976, s. 91-92.

${ }^{35}$ Por. A. Jankowski, Listy więzienne św. Pawła, dz. cyt., s. 226. J.-N. Aletti, Lettera ai Colossesi, dz. cyt., s. 90, zwraca uwagę, że „obraz” w Kol 1, 15 objawia Boga, mimo że sam jest również niewidzialny.

${ }^{36}$ Por. A. Gelin, Pismo Święte o człowieku, dz. cyt., s. 31.
} 
któremu ma się wszystko podporządkować i w którym wszystko ma się po-

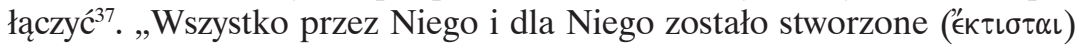

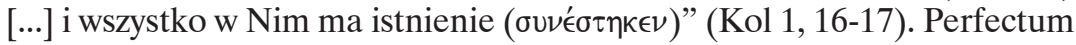

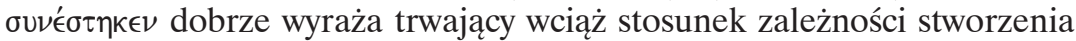
od Chrystusa zapoczątkowany samym aktem stwórczym ${ }^{38}$. Tę jedność Ojca i Syna w ciągle dokonującym się dziele stworzenia już wcześniej oddał Paweł w 1 Kor 8, 6: „dla nas istnieje tylko jeden Bóg, Ojciec, od którego wszystko pochodzi i dla którego my istniejemy, oraz jeden Pan, Jezus Chrystus, poprzez którego wszystko się stało i dzięki któremu także my jesteśmy”.

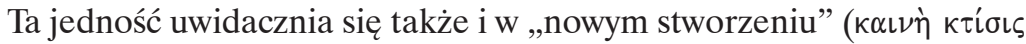
- 2 Kor 5, 17; Ga 6, 15). Ujmuje ją Paweł zwięźle w omawianym hymnie: "Zechciał bowiem [Bóg], ${ }^{39}$ [...] aby przez Niego [Syna] znów pojednać wszystko ze sobą [...], wprowadziwszy pokój przez krew Jego krzyża” (Kol $1,19)^{40}$. Owocem tego dzieła jest życie łaski, która z kolei jest gwarancją „zmartwychwstania do życia” (J 5, 29). To podwójne zmartwychwstanie - z grzechu i ze śmierci - jest także dziełem i Ojca, i Syna: „Albowiem jak Ojciec wskrzesza umarłych i ożywia, tak również i Syn ożywia" (J 5, 21; por. 5, 25; Ef 2, 5). Bóg przywróci do życia nasze śmiertelne ciała (por. Rz 8, 11 ; 1 Kor 6, 14; 2 Kor 4, 14; 1 Tes 4, 14), również i Chrystus ma moc wskrzeszania w dzień ostateczny (por. J 5, 28-29; 6, 39. 40. 44. 54; Flp 3, 21).

Udział Chrystusa w stworzeniu iw „nowym stworzeniu” zapewnia jedność wszystkich stworzeń i tożsamość planów Bożych, gdyż jest On „Początkiem”

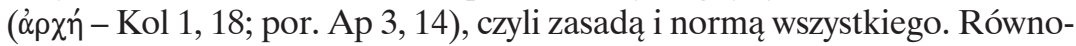
cześnie udział ten stanowi o Jego prymacie. Chrystus ma „pierwszeństwo

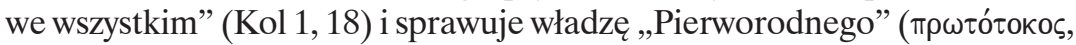
hebr. $\left.b^{e} \underline{k} \hat{o} r\right)$ zarówno w odniesieniu „do każdego stworzenia” $(1,15)$, jak i do zmartwychwstania umarłych (por. 1, 18; Ap 1, 5; 1 Kor 15, 20. 23; Dz 26, 23; Ap 1, 18; 2, 8) i życia w chwale (por. Rz 8, 29; Hbr 2, 10-11. 17) ${ }^{41}$.

Mesjański tytuł „Pierworodny” łączący się z „obrazem” jednym obliczem zwrócony jest ku stworzeniu, a drugim ku transcendencji: Chrystus sprawuje władzę Pierworodnego nad każdym stworzeniem, bo sam przed jakimkolwiek stworzeniem jest zrodzony ${ }^{42}$. Zatem „obraz” trzeba odnieść nie tylko do podobieństwa Chrystusa z Bogiem, ale i do pochodzenia od

${ }^{37}$ Por. A. Jankowski, Listy więzienne św. Pawła, dz. cyt., s. 228-229; J.-N. Aletti, Lettera ai Colossesi, dz. cyt., s. 91-97.

${ }^{38}$ Por. A. Jankowski, Listy więzienne św. Pawła, dz. cyt., s. 230.

${ }^{39}$ Za takim uzupełnieniem podmiotu (Bóg), a nie innym (Pełnia) przemawia więcej argumentów; por. A. Jankowski, Listy więzienne św. Pawła, dz. cyt., s. 233-234.

${ }^{40}$ Por. J.-N. Aletti, Lettera ai Colossesi, dz. cyt., s. 97-104.

${ }^{41}$ Por. H. Schlier, Der Römerbrief, Freiburg-Basel-Wien 1977, s. 272.

${ }^{42}$ Por. L. Cerfaux, Le Christ dans la théologie de saint Paul, Paris ${ }^{2} 1954$, s. 336. 
Boga. Chrystus jest „Jednorodzonym” (J 1, 14. 18; 3, 18; 1 J 4, 9), „umiłowanym Synem" Ojca (Kol 1, 13; Mt 3, 17; 17, 5). Stąd między Nim a Bogiem istnieje ścisła jedność (por. J 10, 30; 1, 10; 16, 15.32; 17, 10. 21-22): istnienia (por. Wj 3, 14 oraz J 8, 24. 28. 58; 13, 19), życia (por. 5, 26), działania (por. $5,17-19)$ i podobieństwo wyrażające się w zwrocie: „Kto Mnie widzi, widzi także i Ojca" $\left(14,9\right.$; por. 12, 45) ${ }^{43}$. Równość z Bogiem (por. J 5, 18; Flp 2,6) i pełne objawianie Boga (por. Mt 11, 27; Łk 10, 22) jest możliwe dla Chrystusa dzięki Jego Boskiemu synostwu. Stanowi ono rację dla Jego bycia obrazem. Zwrot „być Synem” wydaje się być zarazem inną formą zwrotu „być obrazem”. Wyrażenia te pokrywają się w znacznej mierze ${ }^{44}$.

\section{HBR 1, 3}

Myśl św. Pawła podejmuje autor Listu do Hebrajczyków, który w prologu $(1,1-4)$ daje syntezę wypowiedzi Pawła na temat Chrystusa jako „obrazu Boga”, chociaż przy użyciu innych terminów. Ukazuje Chrystusa jako Syna, który ma udział w dziele stworzenia: ,przez Niego [...] stworzył [Bóg] wszechświat”, sam Chrystus „podtrzymuje wszystko słowem swej potęgi” (1, 2. 3). Także „nowe stworzenie” jest dziełem Chrystusa, który „dokonawszy oczyszczenia z grzechów”, sam jako pierwszy „zasiadł po prawicy Majestatu na wysokościach" $(1,3)$. Przychodząc na świat, Syn staje się pełną epifanią Słowa Bożego: przez Niego ('€v vị̣̂) Bóg przemówił do nas w sposób otateczny (por. 1, 2).

Jako Syn jest Chrystus ,odblaskiem Jego [Boga] chwały i odbiciem Jego

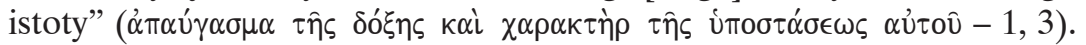
Rzeczownik á $\pi \alpha u ́ \gamma \alpha \sigma \mu \alpha$, występujący jeszcze tylko w Mdr 7, 26, posiada tu znaczenie bierne (odblask, refleks), a nie czynne (błyszczenie, promieniowanie). Przemawia za tym bierne znaczenie drugiego terminu ( $\chi \alpha \rho \alpha \kappa \tau) \rho)$

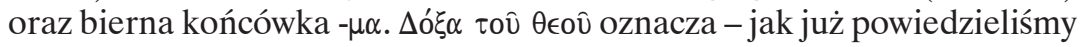
- ujawnienie Bożej obecności (por. Wj 16, 13-15; 24, 17; 40, 34; 1 Krl 8, 10-13), a nawet samego Boga (por. Wj 24, 10; 33, 19-22; Iz 6, 1). Pierwsze

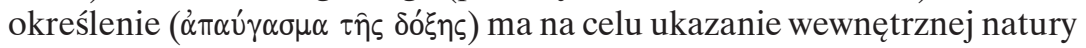
Syna w Jego stosunku do Ojca i uwypukla jedność Chrystusa z Bogiem, przy zachowaniu jednak Ich tożsamości: Syn pochodzi od Ojca (przedrostek àmo- wskazuje na źródło promieniowania), zachodzi jednak między Nimi różnica jakby między skutkiem a przyczyną (końcówka - $\mu \alpha$ wskazuje na odbiorcę), a jednocześnie ścisły i nieprzerwany związek (promieniowania nie można odłączyć od źródła światła), a także podobieństwo (promieniowanie i światło są tej samej natury) $)^{45}$.

${ }^{43}$ Por. P. Lamarche, Obraz, art. cyt., s. 595.

${ }^{44}$ Por. G. Kittel, Eikẃv, art. cyt., s. 394. 


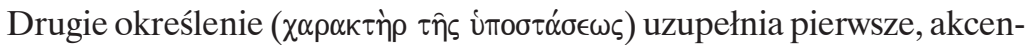
tuje bardziej ontyczną samoistność różnych osób, które są złączone węzłem tej samej natury: „Syn jako oddzielna i samoistna osoba mieści w sobie istotę

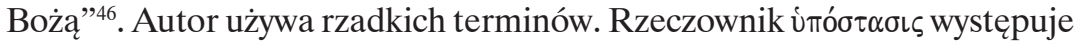
tylko kilka razy w Piśmie Świętym w różnych znaczeniach. W naszym tekście ma znaczenie quasi-filozoficzne; wyraża to, co nie podpada pod zmysły, ale kryje się pod przymiotami jakiegoś bytu, czyli wyraża substancję, istotę danego bytu. Konkretnie tutaj jest określeniem Bożej istoty w Jej realnym,

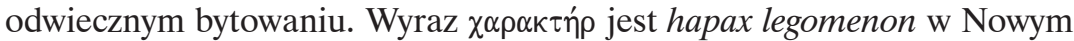
Testamencie, a w Starym spotykamy go tylko w Kpł 13, 28 i 2 Mch 4, 10. Oznacza wyciśnięte podobieństwo, dokładny obraz, wierną reprodukcję. W przeniesieniu na osobę rzeczownik ten uwydatnia odbicie właściwe tylko danej osobie. Jest przy tym terminem mocniejszym od єik $\omega \nu$, bo „odbicie” powstaje przez zetknięcie prototypu i reprodukcji, podczas gdy „obraz” maluje się z pewnego oddalenia, przez co jest mniej wierny ${ }^{47}$.

Autor Listu do Hebrajczyków kreśli w kilku zdaniach wspaniałą syntezę tego, co o Chrystusie jako „obrazie Boga” powiedział św. Paweł. Sprowadza się ona do twierdzenia: „Syn [...] jest obrazem adekwatnym Ojca, gdyż ma z Nim identyczną istotę" ${ }^{4}$.

\section{Podsumowanie}

Nowy Testament, przede wszystkim św. Paweł, kontynuuje motyw obrazu, obecny w Starym Testamencie i rozwijany w judaizmie hellenistycznym. W pismach Starego Testamentu motyw ten jest odnoszony do człowieka (por. Rdz 1, 26-27; Mdr 2, 23; Syr 17, 3 ) i Mądrości (por. Mdr 7, 26). W Nowym Testamencie człowiek pozostaje obrazem Boga (por. 1 Kor 11, 7; Kol 3, 10; $\mathrm{Jk} 3,9$ ), ale prawdziwym i niedościgłym obrazem Boga jest Chrystus (por. 2 Kor 4, 4; Kol 1, 15; Hbr 1, 3). Zrealizował On w sobie i daleko przekroczył wszystkie rysy obrazu Bożego widoczne w człowieku i Mądrości ${ }^{49}$.

${ }^{45}$ Por. A. VAnHoYe, Christologia a qua initium sumit epistola ad Hebreos (Hbr 1, $2 b$ 4), „Verbum Domini” 43 (1965), s. 50-52; tenże, Situation du Christ, dz. cyt., s. 71-74; H. LANGKAmmer, Hymny chrystologiczne Nowego Testamentu, dz. cyt., s. 147; S. Łach, List do Hebrajczyków, dz. cyt., s. 127.

${ }^{46}$ H. Langkammer, Hymny chrystologiczne Nowego Testamentu, dz. cyt., s. 147.

${ }^{47}$ Por. Por. H. LangKammer, Hymny chrystologiczne Nowego Testamentu, dz. cyt., s. 147; A. VANHOYE, Christologia a qua initium sumit epistola ad Hebreos, art. cyt., s. 52-53; tenże, Situation du Christ, dz. cyt., s. 71, 74-76.

${ }^{48}$ S. ŁACH, List do Hebrajczyków, dz. cyt., s. 128.

${ }^{49}$ Warto zauważyć, że w Starym Testamencie ani człowiek, ani Mądrość nie zostali określeni wprost jako „obraz Boży”, ale tylko jako obraz któregoś z przymiotów Bożych (por. Mdr $2,23 ; 7,26)$. W całym Piśmie Świętym człowiek jest najczęściej określany jako stworzony „na 
Zwrot „obraz Boga” i jego treściowe paralele odniesione do Chrystusa występują zawsze w podniosłym kontekście i wyrażają Jego istotę. Jako Syn Boży, zrodzony przed wiekami przez Ojca, Chrystus jest z Nim związany węzłem tej samej natury, dzieli z Nim istnienie, chwałę i nieśmiertelność, zna Go całkowicie i pozostaje z Nim w nieustannym dialogu oraz współdziała zarówno w dziele stworzenia, jak i zbawienia. Dzięki temu jest Chrystus Panem wszechświata i Dawcą życia, Pierworodnym, początkiem i kresem wszystkiego. W pełni objawia Boga, Jego potęgę, mądrość i miłość, jest Jego reprezentantem i pośrednikiem między Nim a światem. Wcielony Syn jest chwalebnym obrazem Boga w ludzkiej formie. Chwała Boża, która z Nim wtargnęła w świat, nie jest już oślepiająca jak w Starym Testamencie, ale przemieniająca, nie niszczy, lecz ożywia ${ }^{50}$.

Kraków

KS. STANISEAW WRONKA

\section{Riassunto}

\section{Cristo - la più piena immagine di Dio}

Il Nuovo Testamento, soprattutto san Paolo, continua il motivo dell'immagine, presente nell'Antico Testamento e sviluppato nel giudaismo ellenistico. Negli scritti veterotestamentari questo motivo viene riferito all'uomo (cf. Gen 1, 26-27; Sap 2, 23; Sir 17, 3) e alla Sapienza (cf. Sap 7, 26). Nel Nuovo Testamento l'uomo rimane l'immagine di Dio (cf. 1 Cor 11, 7; $\mathrm{Col} 3,10 ; \mathrm{Gc} 3,9)$, ma la vera e incomparabile immagine di Dio è Cristo (cf. 2 Cor 4, 4; Col 1, 15; Eb 1, 3). Egli ha reallizzato in sé e molto trasceso tutti i tratti dell'immagine di Dio percepibili nell'uomo e nella Sapienza.

La locuzione „l'immagine di Dio” e i suoi equivalenti contenutistici riferiti a Cristo si trovano ogni volta in un contesto elevato ed esprimono la Sua essenza. Quale Figlio di Dio, generato dal Padre prima dei secoli, Cristo è legato con Lui con il vincolo della stessa natura, condivide la Sua esistenza, gloria e immortalità, Lo conosce totalmente e sta in un dialogo incessante con Lui, nonché collabora nell'opera sia di creazione, che di salvezza. Per questo Cristo è il Signore dell'universo e Datore di vita, Primogenito, inizio e fine di tutto. Egli rivela pienamente Dio, la Sua potenza, sapienza e amore, è il Suo rappresentante e mediatore tra Lui e il mondo. Il Figlio incarnato è l'immagine di Dio nella forma umana. La gloria di Dio, che con Lui irruppe nel mondo, non è più abbagliante come nell'Antico Testamento, ma trasformante, non rovina, bensì ravviva.

obraz i podobieństwo Boże” (por. Rdz 1, 26-27; 5, 1; 9, 6; Syr 17, 3; Kol 3, 10; Jk 3, 9), co wydaje się wyrażeniem słabszym, gdyż „obraz” nie jest w nim kopią oryginału, lecz modelem służącym do odwzorowania. Tylko w 1 Kor 11, 7 św. Paweł mówi wprost, że „mężczyzna [...]

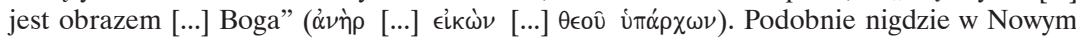
Testamencie nie jest powiedziane, że człowiek ma się stać „obrazem Chrystusa”, ale że ma być ukształtowany według Jego obrazu (por. Rz 8, 29; 1 Kor 15, 49; 2 Kor 3, 18); por. S. Wronka, Upodobnienie chrześcijan do Chrystusa w Nowym Testamencie, „Polonia Sacra” 8 (2004, t. 1) nr 14 (58), s. 301-312; tenże, Racje upodobnienia chrześcijan do Chrystusa w Nowym Testamencie, „Polonia Sacra” 8 (2004, t. 2) nr 15 (59), s. 349-370.

${ }^{50}$ Por. D. Barthélemy, Dieu et son image. Ébauche d'une théologie biblique, Paris 1964, s. 131. 